\title{
Repeated Pancreatectomy for Recurrent Pancreatic Carcinoma after Pylorus-Preserving Pancreatoduodenectomy: Report of Two Patients
}

\author{
Toshitatsu Ogino $^{a}$ Junji Ueda ${ }^{a}$ Norihiro Sato $^{a}$ \\ Shunichi Takahata ${ }^{a}$ Kazuhiro Mizumoto ${ }^{a}$ \\ Masafumi Nakamura ${ }^{a}$ Yoshinao Oda ${ }^{b}$ Masao Tanaka ${ }^{a}$ \\ Departments of a Surgery and Oncology and ${ }^{\mathrm{b}}$ Anatomic Pathology, \\ Graduate School of Medical Sciences, Kyushu University, Fukuoka, Japan
}

\section{Key Words}

Repeated pancreatectomy - Recurrent pancreatic carcinoma - Pylorus-preserving pancreatoduodenectomy

\begin{abstract}
Repeated pancreatectomy for pancreatic carcinoma is extremely rare. We report two such patients who underwent pancreatectomy for carcinoma developing in the pancreatic remnant after pylorus-preserving pancreatoduodenectomy (PpPD) for invasive pancreatic ductal carcinoma. One patient underwent PpPD for invasive pancreatic ductal carcinoma and received adjuvant chemotherapy. Follow-up computed tomography (CT) demonstrated a low-density mass in the remnant pancreas, which was diagnosed as a carcinoma by endoscopic ultrasound-guided fine-needle aspiration cytology 5 years 10 months after PpPD. She underwent curative resection of the remnant pancreas and is alive and well 13 months after the second operation. The other patient underwent PpPD for invasive pancreatic ductal carcinoma. Follow-up CT showed a low-density mass in the remnant pancreas after 2 years 11 months. He received systemic chemotherapy with S-1 for 3 months. The tumor shrank, and the patient underwent curative resection of the remnant pancreas 3 years 1 month after the initial operation. Repeated pancreatectomy may provide a chance of long survival for patients with carcinoma developing in the remnant pancreas after pancreatectomy if the recurrence occurring at long term is limited to the remnant pancreas.
\end{abstract}




\begin{tabular}{c|l|l|l}
$\begin{array}{r}\text { Case Reports in } \\
\text { Gastruanteriology }\end{array}$ & $\begin{array}{l}\text { Case Rep Gastroenterol 2010;4:429-434 } \\
\text { DOI: 10.1159/000321513 }\end{array}$ & $\begin{array}{l}\text { Published online: } \\
\text { October 9, 2010 }\end{array}$ & $\begin{array}{l}\text { O 2010 S. Karger AG, Basel } \\
\text { ISSN 1662-0631 } \\
\text { www.karger.com/crg }\end{array}$ \\
\hline
\end{tabular}

\section{Introduction}

Pancreatic ductal adenocarcinoma (PDAC) is one of the carcinomas with poor prognosis [1]. Complete surgical resection is the only curative treatment for PDAC. However, survival rates after curative resection are still less than $20 \%[2,3]$. Local recurrence in the remnant pancreas, multiple liver metastases, and peritoneal dissemination frequently occur even after curative resection. The chance of repeated pancreatectomy for PDAC developing in the remnant pancreas is quite low [4-13]. However, recent advancement of chemotherapy improves survival rates and may lead to an increase in the chance of repeated pancreatectomy. We report two patients with repeated pancreatectomy for PDAC developing in the remnant pancreas after pylorus-preserving pancreatoduodenectomy $(\mathrm{PpPD})$ for invasive PDAC.

\section{Patient 1}

A 63-year-old woman with previous right modified mastectomy for breast cancer (pStage II, pT2, pN0, M0, according to the International Union Against Cancer (UICC) TNM classification of malignant cancer) in April 1995 presented with loss of appetite, itching, and jaundice in July 2002. Her serum level of carbohydrate antigen 19-9 (CA19-9) was elevated to $57.9 \mathrm{U} / \mathrm{ml}$. Ultrasonography and computed tomography (CT) showed dilation of the main pancreatic duct and common bile duct without a pancreatic head mass. Endoscopic retrograde cholangiopancreatography (ERCP) demonstrated a stricture of both the main pancreatic duct and common bile duct in the head of the pancreas. Endoscopic ultrasound showed a hypoechoic mass, $25 \times 16 \mathrm{~mm}$ in size, in the head of the pancreas. These findings were consistent with a diagnosis of pancreatic head carcinoma. She underwent PpPD and extended lymph node dissection in August 2002. Histopathologically, the tumor consisted of well to moderately differentiated tubular adenocarcinoma invading the adipose tissue, bile duct and duodenal wall (fig. 1). The surgical margin of the resected specimen was free of cancer cells. Regional lymph nodes were metastasized (pStage III, pT3, pN1, M0, according to the UICC TNM classification). After operation, adjuvant therapy with 5-FU and folinic acid was carried out over 6 months.

In August 2004, her blood sugar level was elevated and a treatment of diabetes mellitus was started with oral antidiabetic agents in August 2004. The serum level of CA19-9 rose to $49 \mathrm{U} / \mathrm{ml}$ in February 2008. CT demonstrated a low-density mass, $25 \times 21 \mathrm{~mm}$ in size, in the remnant pancreas in July 2008 (fig. 2). The mass was diagnosed as PDAC by endoscopic ultrasound-guided fine-needle aspiration cytology. The carcinoma was limited inside the pancreatic tissue without distant metastasis and peritoneal dissemination as examined by ultrasonography, CT, magnetic resonance cholangiopancreatography (MRCP) (fig. 3), and positron emission tomography. We performed resection of the remnant pancreas with splenectomy and lymph node dissection in October 2008, 5 years 11 months after PpPD for the initial PDAC. Histopathologically, the second tumor consisted of a well differentiated tubular adenocarcinoma and was limited inside the pancreatic tissue with free surgical margins and regional lymph node metastases (fig. 4). Her postoperative course was uneventful and the CA19-9 level decreased to normal. One month after the second operation, systemic chemotherapy with S-1, 5-chloro-2,4-dihydropyrimidine and potassium oxonate was initiated. The patient is alive and well 13 months after the second operation.

\section{Patient 2}

A 56-year-old man presented with jaundice in February 2007. His serum level of CA19-9 and carcinoembryonic antigen was elevated to $62.2 \mathrm{U} / \mathrm{ml}$ and $9.6 \mathrm{ng} / \mathrm{ml}$, respectively. CT showed dilation of the pancreatic duct and bile duct with an irregular low-density mass, $15 \times 12 \mathrm{~mm}$ in size, in the pancreatic head. ERCP demonstrated an obstruction of both the main pancreatic duct and bile duct. These findings were consistent with a diagnosis of pancreatic head carcinoma. He underwent PpPD with extended lymph node dissection in February 2006. Histological examination showed poorly differentiated adenocarcinoma invading the surrounding adipose tissue and bile duct. The surgical 


\begin{tabular}{r|l|l|l} 
Case Reports in & $\begin{array}{l}\text { Case Rep Gastroenterol 2010;4:429-434 } \\
\text { DOl: 10.1159/000321513 }\end{array}$ & $\begin{array}{l}\text { Published online: } \\
\text { October 9, 2010 }\end{array}$ & $\begin{array}{l}\odot \text { 2010 S. Karger AG, Basel } \\
\text { ISSN 1662-0631 } \\
\text { www.karger.com/crg }\end{array}$ \\
\hline
\end{tabular}

margin was free of atypical cells. Regional lymph nodes were metastasized (pStage IIb, pT1, pN1, M0, according to the UICC TNM classification). After operation, adjuvant chemotherapy with gemcitabine was carried out for 12 months.

The serum CA19-9 level rose to $86 \mathrm{U} / \mathrm{ml}$ in November 2008. Follow-up CT demonstrated a low-density mass, $15 \times 14 \mathrm{~mm}$ in size, in the remnant pancreas (fig. 5 ). He received chemotherapy with S-1 for 3 months and CT scan showed the tumor size decreasing to $10 \mathrm{~mm}$ without distant metastasis. We performed resection of the remnant pancreas with splenectomy and lymph node dissection in March 2009. Histopathologically, the second tumor was a poorly differentiated adenocarcinoma limited inside the pancreatic tissue with free surgical margin and regional lymph node metastases. The postoperative course was uneventful and the patient has been alive and well for 7 months at the time of writing.

\section{Discussion}

Pancreatic carcinoma is known to have a poor prognosis and frequently develops recurrence even after curative resection [14]. The major recurrence pattern of PDAC is local spread in the remnant pancreas, multiple liver metastases and peritoneal dissemination within 1-2 years after resection $[15,16]$. In the present patients, surgical resection of the remnant pancreas was performed because the recurrence of PDAC after PpPD was limited to the remnant pancreas without distant metastasis, nodal involvement and peritoneal dissemination. There have been anecdotal reports of repeated pancreatectomy for recurrent PDAC in the remnant pancreas [4-13]. Some of the previous reports demonstrated long survival after surgical resection for the second PDAC $[5,6,8,10,12]$. These patients and our patients show the same clinical feature, that is, curative resection with negative surgical margins at both the first and second operations. The effectiveness of repeated pancreatectomy for PDAC in the remnant pancreas is obscure because of the lack of a sufficient number of patients, but the safety of repeated pancreatectomy has been reported recently [9]. We believe that repeated pancreatectomy may provide good results in selected patients in whom complete removal of PDAC in the remnant pancreas can be achieved.

It is difficult to clarify whether PDAC developing in the remnant pancreas is a local recurrence or a second primary carcinoma. According to Schnelldorfer et al. [3], 5-year survival after PpPD or pancreatoduodenectomy for PDAC was no guarantee of cure, because $16 \%$ of this subset died of PDAC up to 7.8 years after the operation. On the other hand, Launois et al. [17] observed the incidence of $32 \%$ of multifocal carcinomas in the pancreas in a series of 47 total pancreatectomies for patients with PDAC. Progression of atypical ductal hyperplasia or carcinoma in situ to an invasive PDAC has been documented [18]. A minute cancerous lesion may coexist in the remnant pancreas at the initial operation. In our patients, the second carcinoma seems to be a recurrent lesion because both the first and second cancers showed similar histological characteristics, even with the long interval period between the first and second operations. Although it is obscure whether PDAC in the remnant pancreas is a local recurrence or not, periodic examinations including measurement of tumor markers and imaging studies such as CT scan might have an important role for early detection of PDAC developing in the remnant pancreas after pancreatectomy for PDAC.

Recent advancement of adjuvant and neoadjuvant therapy including chemotherapy and radiotherapy improves the survival benefit in patients undergoing curative resection of PDAC [19-21]. Adjuvant therapy may inhibit the growth of carcinoma in the remnant 


\begin{tabular}{r|l|l|l}
$\begin{array}{r}\text { Case Reports in } \\
\text { Gastruanterology }\end{array}$ & $\begin{array}{l}\text { Case Rep Gastroenterol 2010;4:429-434 } \\
\text { DOl: 10.1159/000321513 }\end{array}$ & $\begin{array}{l}\text { Published online: } \\
\text { October 9, 2010 }\end{array}$ & $\begin{array}{l}\text { O 2010 S. Karger AG, Basel } \\
\text { ISSN 1662-0631 } \\
\text { www.karger.com/crg }\end{array}$ \\
\hline
\end{tabular}

pancreas after pancreatectomy for PDAC. Some PDAC is chemosensitive and preoperative chemotherapy provides a histopathological response and a high R0 resection rate [22]. In our second patient administration of S-1 made the recurrent tumor shrink, and curative resection was performed. Effects of chemotherapy may increase the chance of curative resection of a secondary primary or recurrent pancreatic carcinoma in the remnant pancreas.

In conclusion, curative resection for PDAC developing in the remnant pancreas after PpPD for PDAC may be possible as in our patients. Repeated pancreatectomy may provide a chance of long-term survival if the recurrence of PDAC is limited to the remnant pancreas.

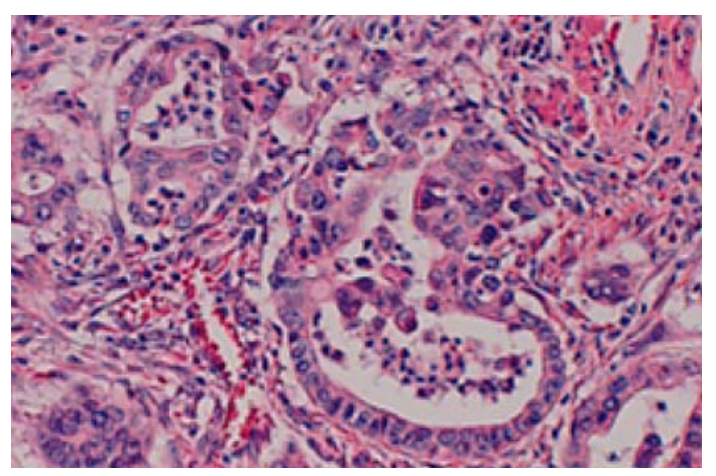

Fig. 1. High-power view of the histopathologic specimen of the first operation demonstrating a well to moderately differentiated tubular adenocarcinoma (HE, 400×).

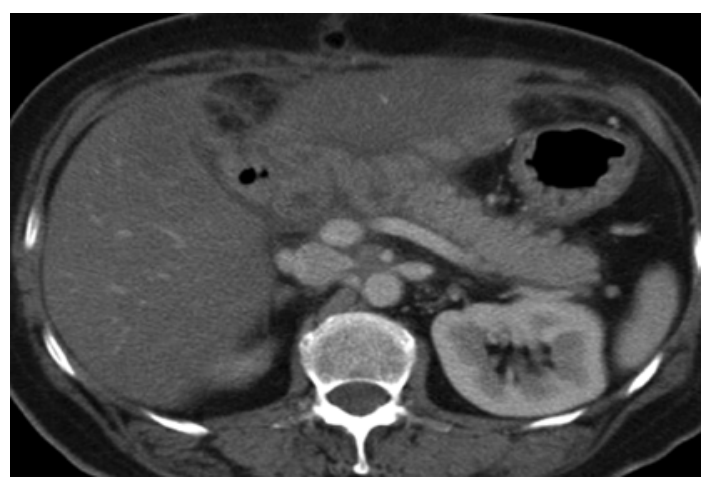

Fig. 2. CT scan showing a pancreatic mass limited inside the pancreas without distant metastasis and peritoneal dissemination. 


\begin{tabular}{l|l|l|l}
$\begin{array}{r}\text { Case Reports in } \\
\text { Gastroenteriology }\end{array}$ & $\begin{array}{l}\text { Case Rep Gastroenterol 2010;4:429-434 } \\
\text { DOI: 10.1159/000321513 }\end{array}$ & $\begin{array}{l}\text { Published online: } \\
\text { October 9, 2010 }\end{array}$ & $\begin{array}{l}\text { O 2010 S. Karger AG, Basel } \\
\text { ISSN 1662-0631 } \\
\text { www.karger.com/crg }\end{array}$ \\
\hline
\end{tabular}

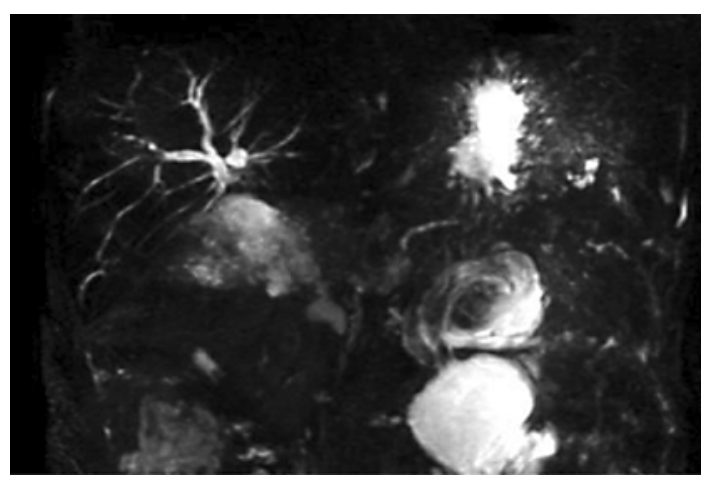

Fig. 3. MRCP shows an obstruction of both the main pancreatic duct and bile duct.

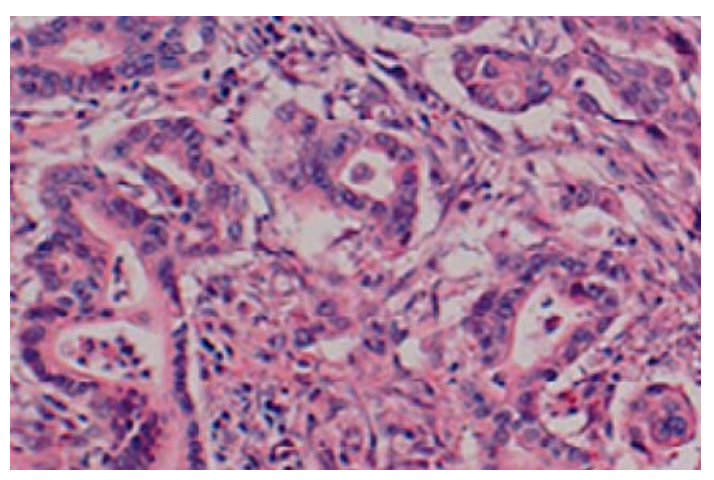

Fig. 4. High-power view of the histopathologic specimen of the second operation (HE, 400×). Histopathologically, the second tumor was a well differentiated tubular adenocarcinoma.

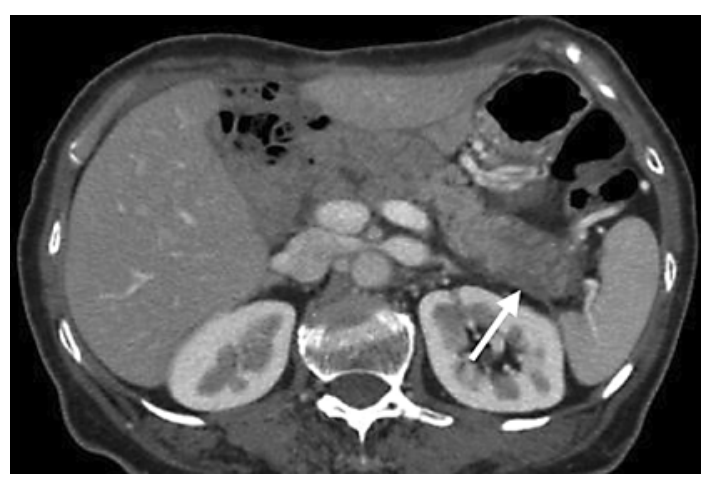

Fig. 5. Follow-up CT scan demonstrating a low-density mass, $15 \times 14 \mathrm{~mm}$ in size, in the remnant pancreas. 


\begin{tabular}{c|l|l|l}
$\begin{array}{r}\text { Case Reports in } \\
\text { Gastruenterology }\end{array}$ & $\begin{array}{l}\text { Case Rep Gastroenterol 2010;4:429-434 } \\
\text { DOI: 10.1159/000321513 }\end{array}$ & $\begin{array}{l}\text { Published online: } \\
\text { October 9, 2010 }\end{array}$ & $\begin{array}{l}\text { O 2010 S. Karger AG, Basel } \\
\text { ISSN 1662-0631 } \\
\text { www.karger.com/crg }\end{array}$ \\
\hline
\end{tabular}

\section{References}

1 Winer E, Gralow J, Diller L, et al: Clinical cancer advances 2008: Major research advances in cancer treatment, prevention, and screening - a report from the American Society of Clinical Oncology. J Clin Oncol 2009;27:812-826.

$\checkmark 2$ Cress RD, Yin D, Clarke L, Bold R, Holly EA: Survival among patients with adenocarcinoma of the pancreas: a population-based study (United States). Cancer Causes Control 2006;17:403-409.

-3 Schnelldorfer T, Ware AL, Sarr MG, Smyrk TC, Zhang L, Qin R, Gullerud RE, Donohue JH, Nagorney DM, Farnell MB: Long-term survival after pancreatoduodenectomy for pancreatic adenocarcinoma: is cure possible? Ann Surg 2008;247:456-462.

- Eriguchi N, Aoyagi S, Imayama H, et al: Resectable carcinoma of the pancreatic head developing 7 years and 4 months after distal pancreatectomy for carcinoma of the pancreatic tail. J Hepatobiliary Pancreat Surg 2000;7:316-320.

$\checkmark 5$ Wada K, Takada T, Yasuda H, Amano H, Yoshida M: A repeated pancreatectomy in the remnant pancreas 22 months after pylorus-preserving pancreatoduodenectomy for pancreatic adenocarcinoma. J Hepatobiliary Pancreat Surg 2001;8:174-178.

-6 D’Amato A, Gentili V, Santella S, Boschetto A, Pronio A, Montesani C: Carcinoma of the pancreatic remnant developing after pancreaticoduodenectomy for adenocarcinoma of the head of pancreas. Chir Ital 2002;54: 539-544.

-7 Takamatsu S, Ban D, Irie T, Noguchi N, Kudoh A, Nakamura N, Kawamura T, Igari T, Teramoto K, Arii S: Resection of a cancer developing in the remnant pancreas after a pancreaticoduodenectomy for pancreas head cancer. J Gastrointest Surg 2005;9:263-269.

-8 Dalla Valle R, Mancini C, Crafa P, Passalacqua R: Pancreatic carcinoma recurrence in the remnant pancreas after a pancreaticoduodenectomy. JOP 2006;7:473-477.

-9 Miura F, Takada T, Amano H, Yoshida M, Isaka T, Toyota N, Wada K, Takagi K, Kato K: Repeated pancreatectomy after pancreatoduodenectomy. J Gastrointest Surg 2007;11:179-186.

-10 Tajima Y, Kuroki T, Ohno T, Furui J, Tsuneoka N, Adachi T, Mishima T, Kosaka T, Haraguchi M, Kanematsu T: Resectable carcinoma developing in the remnant pancreas 3 years after pylorus-preserving pancreaticoduodenectomy for invasive ductal carcinoma of the pancreas. Pancreas 2008;36:324-327.

11 Inoue K, Kosuge T, Shimada K, Yamamoto J, Takayama T, Ozaki H, Nose H: Repeated radical resection and intraoperative irradiation for recurrent pancreatic ductal adenocarcinoma after pancreatoduodenectomy. Surgery 1995;118:909-911.

-12 Kleeff J, Reiser C, Hinz U, Bachmann J, Debus J, Jaeger D, Friess H, Buchler MW: Surgery for recurrent pancreatic ductal adenocarcinoma. Ann Surg 2007;245:566-572.

13 Doi R, Ikeda H, Kobayashi H, Kogire M, Imamura M: Carcinoma in the remnant pancreas after distal pancreatectomy for carcinoma. Eur J Surg Suppl 2003;588:62-65.

14 Sperti C, Pasquali C, Piccoli A, Pedrazzoli S: Recurrence after resection for ductal adenocarcinoma of the pancreas. World J Surg 1997;21:195-200.

-15 Hishinuma S, Ogata Y, Tomikawa M, Ozawa I, Hirabayashi K, Igarashi S: Patterns of recurrence after curative resection of pancreatic cancer, based on autopsy findings. J Gastrointest Surg 2006;10:511-518.

-16 Van den Broeck A, Sergeant G, Ectors N, Van Steenbergen W, Aerts R, Topal B: Patterns of recurrence after curative resection of pancreatic ductal adenocarcinoma. Eur J Surg Oncol 2009;35:600-604.

17 Launois B, Franci J, Bardaxoglou E, Ramee MP, Paul JL, Malledant Y, Campion JP: Total pancreatectomy for ductal adenocarcinoma of the pancreas with special reference to resection of the portal vein and multicentric cancer. World J Surg 1993;17:122-126; discussion 126-127.

18 Patel AG, Reber PU, Toyama MT, Ashley SW, Reber HA: Effect of pancreaticojejunostomy on fibrosis, pancreatic blood flow, and interstitial pH in chronic pancreatitis: a feline model. Ann Surg 1999;230:672-679.

19 Oettle H, Post S, Neuhaus P, et al: Adjuvant chemotherapy with gemcitabine vs observation in patients undergoing curative-intent resection of pancreatic cancer: a randomized controlled trial. JAMA 2007;297: 267-277.

20 Abbruzzese JL: Adjuvant therapy for surgically resected pancreatic adenocarcinoma. JAMA 2008;299: 1066-1067.

-21 Heinrich S, Pestalozzi BC, Schafer M, Weber A, Bauerfeind P, Knuth A, Clavien PA: Prospective phase II trial of neoadjuvant chemotherapy with gemcitabine and cisplatin for resectable adenocarcinoma of the pancreatic head. J Clin Oncol 2008;26:2526-2531.

-22 Le Scodan R, Mornex F, Partensky C, Mercier C, Valette PJ, Ychou M, Roy P, Scoazec JY: Histopathological response to preoperative chemoradiation for resectable pancreatic adenocarcinoma: the French Phase II FFCD 9704-SFRO Trial. Am J Clin Oncol 2008;31:545-552. 